\title{
Properties of carbonaceous materials from sewage sludge to remove organic matter. Phenol as a particular case
}

\author{
S. Pinedo-Hernández ${ }^{a}$, E. Gutiérrez-Segura ${ }^{a}$, M. Solache-Ríos ${ }^{\mathrm{b}, *}$, A. Colín-Cruz \\ aUniversidad Autónoma del Estado de México, Facultad de Química. Paseo Colón esq. Paseo Tollocan, S/N. C.P. 50180, Toluca, \\ México,email: samantha_pinedo@yahoo.com.mx (S.Pinedo-Hernández), eegutierrezs@uaemex.mx (E. Gutiérrez-Segura), \\ acolinc@uaemex.mx (A.Colin-Cruz). \\ ${ }^{b}$ Instituto Nacional de Investigaciones Nucleares, Departamento de Química. Carretera México-Toluca S/N, km. 36.5. La Marquesa \\ Ocoyoacac, Apartado Postal 18-1027, México DF, Tel. +52 5553297200 x2271, email: marcos.solache@inin.gob.mx
}

Received 29 August 2016; Accepted 22 February 2017

\section{A B S T R AC T}

Carbonaceous material obtained from the pyrolysis of sewage sludge, activated carbon (AC), a composite $\mathrm{CM}(\mathrm{Fe}-\mathrm{Cu})$ (carbonaceous material/nanoparticles of $\mathrm{Fe}-\mathrm{Cu}$ ) and nanoparticles $\mathrm{N}(\mathrm{Fe}-\mathrm{Cu}$ ) were used to evaluate and compare their abilities to remove phenol from aqueous solutions by adsorption followed by oxidation. The adsorbents were characterized by scanning electron microscopy, transmittance electron microscopy, Brunauer-Emmett-Teller (BET) surface area, X-ray diffraction and Infrared (IR) spectroscopy. The presence of Fe-Cu nanoparticles was confirmed by the TEM technique. Sorption kinetics and isotherms were determined in the presence and absence of hydrogen peroxide. The experimental kinetic data of the activated carbon and the carbonaceous material were treated with Lagergren, Elovich and Ho models. The results show that both materials are best fit to the second order model indicating a chemisorption mechanism. The adsorption equilibrium of phenol by the different adsorption materials was observed in $24 \mathrm{~h}$. The adsorption capacity of $\mathrm{CM}(\mathrm{Fe}-\mathrm{Cu})$ for phenol was not affected by the $\mathrm{pH}$, and the adsorption capacities for $\mathrm{CM}$ and $\mathrm{AC}$ decreased as the $\mathrm{pH}$ increased. The isotherms were lineal in all cases. $\mathrm{N}(\mathrm{Fe}-\mathrm{Cu})$ was the most efficient material for the removal of phenol from aqueous solutions. The adsorption capacities decreased as the doses increased and the adsorption capacities of the materials were not affected by the temperature when it was between 30 and $50^{\circ} \mathrm{C}$; only the composite $\mathrm{CM}(\mathrm{Fe}-\mathrm{Cu})$ in the presence of hydrogen peroxide showed an endothermic behavior. The highest adsorption capacities were for $\mathrm{N}(\mathrm{Fe}-\mathrm{Cu})$ in the presence and absence of hydrogen peroxide.

Keywords: Sewage sludge; Phenol; Nanoparticles; Fenton; Adsorption; Carbon

\section{Introduction}

In the past many adsorbents for organic and inorganic pollutants have been investigated, and the search for lowcost adsorbents has been intensified. Sewage sludge produced from wastewater treatment is a serious problem [1], because of its composition. The sludge could contain inorganic and organic contaminants, including some persistent contaminants [2]. Therefore, it would be beneficial to use these waste materials by turning them into resources.

${ }^{*}$ Corresponding author.
Recently, sewage sludge has been used to produce carbonaceous materials [3].

Phenol is one of the pollutants that seriously damages ecosystems and is considered as a priority pollutant by USEPA, with a maximum limit of $0.5 \mathrm{mg} / \mathrm{g}$ [4]. Mexican regulations establish a limit of tolerance for phenol in drinking water of $0.001 \mathrm{mg} / \mathrm{L}$ [5].

The presence of phenolic compounds in wastewater is a growing concern because the presence of high concentrations is a serious potential risk to human health and aquatic life [6-10]. It is therefore important to develop 
effective techniques to remove phenol from wastewater. In general, organic pollutants are removed by chemical treatments like acid-base neutralization, precipitation, adsorption and oxidation-reduction [10-13]. The adsorption process is an important method because it is efficient to remove phenolic compounds and derivative pollutants, even at low concentrations and it makes possible an attractive technology when the adsorbent is cheap and easy to use $[14,15]$

Several adsorbents have been evaluated, such as silica gel, alumina, zeolites, activated charcoal, sawdust, peat, lignite and red mud [16]. Activated carbon is the sorbent most widely used to remove organic contaminants from water due to its porous structure, high surface area, high removal efficiency and feasibility for large-scale use [15]. However, it presents certain problems due to its high cost and regeneration [17].

The most common advanced oxidation processes include: Fenton processes $\left(\mathrm{H}_{2} \mathrm{O}_{2} / \mathrm{Fe}^{2+}\right)$, ultraviolet (UV)/ $\mathrm{H}_{2} \mathrm{O}_{2}, \mathrm{UV} / \mathrm{O}_{3}, \mathrm{O}_{3} / \mathrm{H}_{2} \mathrm{O}_{2}$, and photocatalytic degradation with $\mathrm{TiO}_{2} / \mathrm{UV}$. Fenton and Fenton-like processes are effective at degrading organic pollutants in wastewater $[3,6,9$, 10,12,18-20].

In the Fenton process, $\mathrm{H}_{2} \mathrm{O}_{2}$ in the presence of a catalysts such as iron enhances oxidation by generating $\mathrm{HO}$ radicals that react with the organic matter $[9,10,12,13,20-23]$.

Fenton reactions can be of two types: homogeneous, also called a conventional reaction, and heterogeneous. In the homogenous reaction, diluted $\mathrm{H}_{2} \mathrm{O}_{2}$ reacts with $\mathrm{Fe}^{2+}$ in a solution, producing the radical $\mathrm{OH}^{2}$ at $\mathrm{pH}$ values near 3 . However, it is impractical to use the homogeneous process because large amounts of iron hydroxide sludge are formed as a byproduct $[8,22,24,25]$.

Several solid catalysts, including activated carbon impregnated with iron and copper, have been used to degrade recalcitrant organic compounds by the Fenton reaction [18]. However, these catalysts require UV radiation to accelerate the reduction. Catalysts have been developed with nanoparticles with a high surface area which can accelerate the Fenton reaction without UV radiation. These nanocatalysts are very reactive because their active sites are on the surface. They have a low diffusion resistance, and are easily accessible to substrate molecules $[10,18,19,26]$.

Iron nanoparticles have special catalytic and photochemical properties for degradation of organic pollutants [11]. Nanoparticles of $\mathrm{Fe} / \mathrm{Cu}$ have been synthesized to improve the efficiency of pollutant degradation [20,27]. The results for the removal of 4-chlorophenol from aqueous solutions by modified zeolitic material with hexadecyl trimethyl ammonium bromide, using batch and (column) systems showed that the mechanism was chemisorption and the isotherm was linear [28].

Vinita et al. [29] investigated the degradation of 2,4,6-trichlorophenol with Fe nanoparticles, the degradation was $86 \%$ at $\mathrm{pH}-3$. Ninety percent of $\mathrm{p}$-nitrophenol was degraded after $10 \mathrm{~h}$ with $1.5 \mathrm{~g} / \mathrm{L} \mathrm{Fe}_{3} \mathrm{O}_{4}$ and $\mathrm{pH} 7.0$ using nano-magnetite [24]. $\mathrm{FeO}$ and $\mathrm{CuO}$ materials have been used for the degradation of nitrobenzene [20].

The aim of this study was twofold, first to obtain carbonaceous material from sewage sludge and a composite $\mathrm{CM}(\mathrm{Fe}-\mathrm{Cu})$ (carbonaceous material/nanoparticles of
$\mathrm{Fe}-\mathrm{Cu}$ ); the second was to determine their removal properties of phenol from aqueous solutions and compare their efficiencies with those of nanoparticles $\mathrm{N}(\mathrm{Fe}-\mathrm{Cu})$. The removal of phenol has been reported by the adsorption or oxidation process by different materials. The novelty of this paper is that new materials were used to remove phenol from aqueous solutions, and both adsorption and then oxidation of phenol by Fenton-type reactions were applied in the same process.

\section{Experimental}

\subsection{Materials and methods}

A phenol stock solution was prepared using deionized water and analytical grade phenol. Phenol concentrations in solutions were determined by using a UV/Vis Perkin Elmer Lambda 10 spectrophotometer, with a wavelength of $270 \mathrm{~nm}$. A $30 \% \mathrm{H}_{2} \mathrm{O}_{2}$ solution (analytical grade) was used.

\subsection{Carbonaceous material (CM)}

Sewage sludge was obtained from an industrial sewage treatment plant (Reciclagua, Lerma, Mexico). It was dried at $20^{\circ} \mathrm{C}$ and pyrolysis of the sludge was performed at $600^{\circ} \mathrm{C}$ for $1 \mathrm{~h}$ in stainless steel reactor and nitrogen atmosphere. After the treatment, it was triturated and the grains of sizes between $0.42 \mathrm{~mm}$ and $0.84 \mathrm{~mm}$ were selected.

The carbonaceous material obtained $(\mathrm{CM})$ was treated with an $18 \%$ hydrochloric acid solution at $20^{\circ} \mathrm{C}$ for $4 \mathrm{~h}$ to activate the carbonaceous material and remove any metals that could be present in the sample, then it was washed 5 times with distilled water and dried at $60^{\circ} \mathrm{C}$ for $5 \mathrm{~h}$. Additionally, a commercial activated carbon (AC) which was prepared from wood, was obtained from Clarimex®.

\subsection{Nanoparticles $\mathrm{N}(\mathrm{Fe}-\mathrm{Cu})$ and composite carbonaceous material/nanoparticles $\mathrm{N}(\mathrm{Fe}-\mathrm{Cu})(\mathrm{CM}(\mathrm{Fe}-\mathrm{Cu})$}

Nanoparticles of $\mathrm{Fe}-\mathrm{Cu}$ and composite $\mathrm{CM}(\mathrm{Fe}-\mathrm{Cu})$ $(75 / 25 \% \mathrm{wt} \%$ ratio) were synthesized by chemical reduction. Nanoparticles were prepared as follows: $0.01 \mathrm{M}$ solutions of $\mathrm{FeSO}_{4} \cdot 7 \mathrm{H}_{2} \mathrm{O}$ and $\mathrm{CuSO}_{4} \cdot 5 \mathrm{H}_{2} \mathrm{O}$ were mixed and left stirring for $24^{2} \mathrm{~h}$, then a $0.01^{4} \mathrm{M} \mathrm{NaBH}_{4}$ solution was added to reduce the metals. The composite was prepared as above; carbonaceous material was added before reduction with an $\mathrm{NaBH}_{4}$ solution. The resulting mixtures were vacuum filtered; the materials obtained were washed with distilled water and alcohol, and then finally air-dried for $24 \mathrm{~h}$.

\subsection{Characterization}

\subsubsection{Scanning electron microscopy}

For scanning electron microscopy (SEM) observations, the materials before and after phenol adsorption were mounted directly on the holders and then observed at 10 $\mathrm{kV}$ in a JEOL JSM-5900-LD electron microscope. The microanalysis was done with an energy X-ray dispersive spectroscopy (EDS) system. 


\subsubsection{IR spectroscopy}

The IR spectra of adsorbents before and after adsorption of phenol were obtained at room temperature in the wavelength range of $4000-800 \mathrm{~cm}^{-1}$ using a Shimadzu Prestige21 FTIR.

\subsubsection{X-ray diffraction (XRD)}

Powder diffractograms were obtained by using a Siemens D500 diffractometer coupled to a copper anode X-ray tube. The conventional diffractograms were compared with the Joint Committee on Powder Diffraction Standards (JCPDS).

\subsubsection{TEM observations}

Nanoparticles and composite $\mathrm{CM}(\mathrm{Fe}-\mathrm{Cu})$ were suspended in 2-propanol using an ultrasonic instrument. TEM samples were prepared by placing a drop of the alcoholic suspension on carbon-coated copper grids. TEM observations were performed by using a transmission electron microscope JEOL-2010, operated at an accelerating voltage of $200 \mathrm{kV}$ and equipped with a LaB6 filament.

\subsubsection{Specific surface areas (BET)}

The BET specific surface areas were determined by standard multipoint techniques of nitrogen adsorption, by using a Micromeritics Gemini 2360 instrument. The samples were heated at $200^{\circ} \mathrm{C}$ for $2 \mathrm{~h}$ before specific surface areas were measured.

\subsection{Sorption kinetics}

Kinetic removal of phenol by the adsorbent materials (carbonaceous material (CM), activated carbon (AC), composite $(\mathrm{CM}(\mathrm{Fe}-\mathrm{Cu}))$ and nanoparticles $(\mathrm{N}(\mathrm{Fe}-\mathrm{Cu}))$ was performed as follows: $100 \mathrm{mg}$ of each adsorbent and $10 \mathrm{~mL}$ aliquots of a $10 \mathrm{mg} / \mathrm{L}$ solution of phenol were placed in centrifuge tubes and shaken for different periods of time at $120 \mathrm{rpm}$ and $20^{\circ} \mathrm{C}$, then the samples were centrifuged and decanted. All adsorption experiments were performed in duplicate.

$\mathrm{CM}(\mathrm{Fe}-\mathrm{Cu})$ and $\mathrm{N}(\mathrm{Fe}-\mathrm{Cu})$ were used for the Fenton process; $3 \mathrm{~mL}$ of a $30 \% \mathrm{H}_{2} \mathrm{O}_{2}$ solution were placed in $7 \mathrm{~mL}$ of the phenol solution $(10 \mathrm{mg} / \mathrm{L})$ at $\mathrm{pH} 3$ and $100 \mathrm{mg}$ of the adsorbent were added.

\subsection{Sorption isotherms}

One hundred milligram samples of each material were put into contact with $10 \mathrm{~mL}$ of different concentrations of phenol solutions (from 1 to $120 \mathrm{mg} / \mathrm{L}$ ) for $72 \mathrm{~h}$ at $20^{\circ} \mathrm{C}$. Later, the samples were centrifuged and decanted. Phenol concentrations were determined in the remaining liquid phases by using a UV / Vis spectrophotometer.

$\mathrm{CM}(\mathrm{Fe}-\mathrm{Cu})$ and $\mathrm{N}(\mathrm{Fe}-\mathrm{Cu})$ were used for the Fenton process; $3 \mathrm{~mL}$ of $30 \% \mathrm{H}_{2} \mathrm{O}_{2}$ solution were placed in $7 \mathrm{~mL}$ of phenol solution (from 1 to $120 \mathrm{mg} / \mathrm{L}$ ) at $\mathrm{pH} 3$, and $100 \mathrm{mg}$ of the solid materials were added.

\subsection{Effect of $p H$}

In order to determine the effect of $\mathrm{pH}$ on phenol adsorption processes, experiments were carried out using $10 \mathrm{~mL}$ of a $10 \mathrm{mg} / \mathrm{L}$ solution of phenol and $100 \mathrm{mg}$ of adsorbent. The initial $\mathrm{pH}$ values were adjusted by adding $\mathrm{HCl}$ or $\mathrm{NaOH}$ solutions; the $\mathrm{pH}$ values of the solutions were $3,4,5,8$ and 11. The $\mathrm{pH}$ of each solution was measured periodically and was kept constant until it reached equilibrium; the experiments were performed in duplicate. Subsequently the phases were separated, and phenol concentrations were determined in the remaining solutions by UV/Vis spectrometry.

\subsection{Effect of the adsorbent dosage}

Experiments were carried out using different amounts of adsorbent $(1,3,5,7,9,11,13,15,17$ and $20 \mathrm{mg})$ and $10 \mathrm{~mL}$ of a phenol solution $(10 \mathrm{mg} / \mathrm{L})$ at $\mathrm{pH} 3$. The mixtures were shaken $72 \mathrm{~h}$; subsequently the phases were separated, and the concentration of phenol in the remaining solutions was determined by UV/Vis spectrometry. $\mathrm{CM}(\mathrm{Fe}-\mathrm{Cu})$ and $\mathrm{N}(\mathrm{Fe}-\mathrm{Cu})$ were used for the Fenton process; $3 \mathrm{~mL}$ of $30 \% \mathrm{H}_{2} \mathrm{O}_{2}$ solution were placed in $7 \mathrm{~mL}$ of phenol solution $(10 \mathrm{mg} / \mathrm{L})$ at $\mathrm{pH} 3$, together with $100 \mathrm{mg}$ of the solid materials.

\subsection{Effect of temperature}

The experiments were performed using $100 \mathrm{mg}$ of each adsorbent material and $10 \mathrm{~mL}$ of a phenol solution (10 $\mathrm{mg} / \mathrm{L}$ ) of $\mathrm{pH} 3$ and the mixtures were shaken at $120 \mathrm{rpm}$ for $72 \mathrm{~h}$. The experiments were carried out at 30,40 and $50^{\circ} \mathrm{C}$. Thereafter the phases were separated and the concentration of phenol in the solution was determined by UV/Vis spectrometry. $\mathrm{CM}(\mathrm{Fe}-\mathrm{Cu})$ and $\mathrm{N}(\mathrm{Fe}-\mathrm{Cu})$ were used for the Fent on process; $3 \mathrm{~mL}$ of a $30 \% \mathrm{H}_{2} \mathrm{O}_{2}$ solution were added to $7 \mathrm{~mL}$ of phenol solution of $10 \mathrm{mg} / \mathrm{L}$ of $\mathrm{pH} 3$.

\section{Results and discussion}

\subsection{Characterization}

\subsubsection{Scanning electron microscopy}

Figs. $1 \mathrm{a}$ and $1 \mathrm{~b}$ show images of raw carbonaceous material and the same material after being in contact with phenol, respectively. The materials show irregular morphologies and cavities of different sizes which confers porosity on the materials; similar observation shave been reported elsewhere [30]. Figs. 2a, $2 b$ and $3 a, 3 b$ show images of $\mathrm{CM}(\mathrm{Fe}-\mathrm{Cu}), \mathrm{N}(\mathrm{Fe}-\mathrm{Cu})$ and the same after being treated with phenol respectively; the morphology of the materials shows porosity on their surfaces.

Chemical composition of the adsorbents before and after adsorption of phenol is shown in Table 1; the elemental composition of the materials before and after adsorption of phenol was similar. The carbon content was $82 \%, 62 \%$ and $59 \%$ for $\mathrm{AC}, \mathrm{CM}$ and $\mathrm{CM}(\mathrm{Fe}-\mathrm{Cu})$ respectively. Other elements found were calcium and sulfur; calcium was found in $\mathrm{CM}(\mathrm{Fe}-\mathrm{Cu})(2.37 \%)$ and $\mathrm{CM}(1.24 \%)$. Sulfur concentrations of $1.00,1.33$ and $0.49 \%$ were present in $\mathrm{C}(\mathrm{Fe}-\mathrm{Cu}), \mathrm{CM}$ 

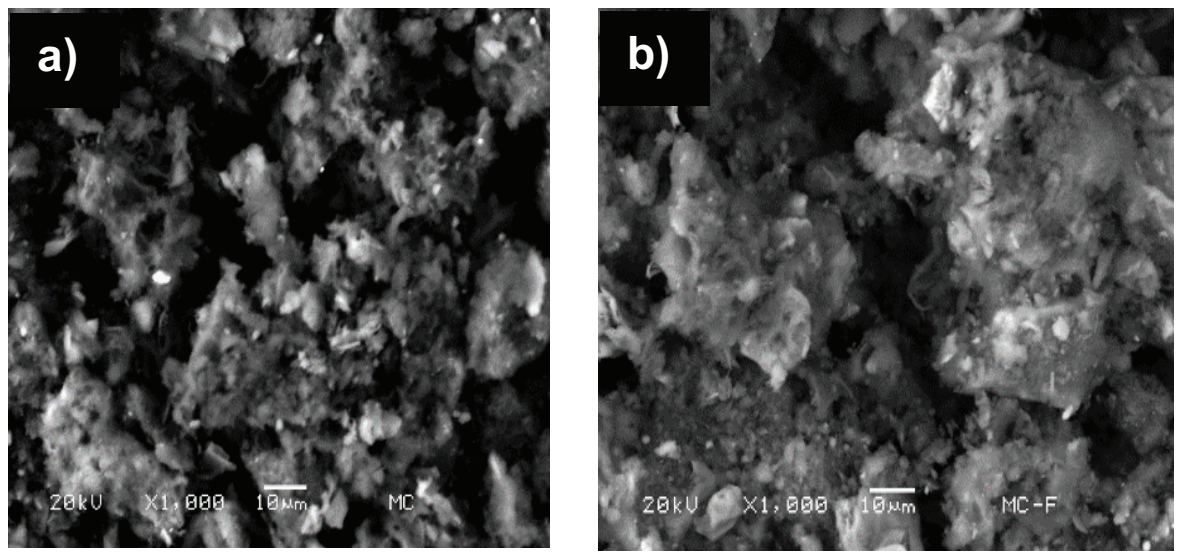

Fig. 1. Scanning-electron micrographs of carbonaceous material CM (a) and carbonaceous material treated with phenol CM-F(b).
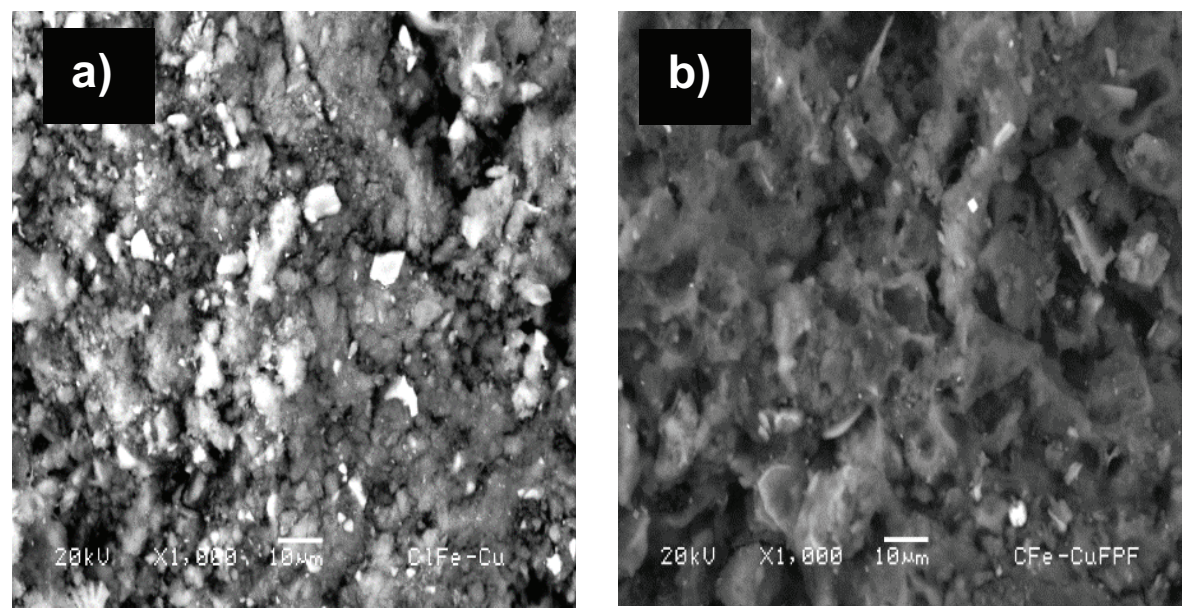

Fig. 2. Scanning-electron micrograph of a) composite $\mathrm{CM}(\mathrm{Fe}-\mathrm{Cu})$ and $\mathrm{b})$ material treated with phenol.

Table 1

Elemental composition of $\mathrm{AC}, \mathrm{CM}, \mathrm{C}(\mathrm{Fe}-\mathrm{Cu})$ y N(Fe-Cu) before and after adsorption of phenol

\begin{tabular}{lllllllll}
\hline Element & $\begin{array}{l}\text { AC } \% \\
\text { weight }\end{array}$ & $\begin{array}{l}\mathrm{CM} \% \\
\text { weight }\end{array}$ & $\begin{array}{l}\mathrm{CM}(\mathrm{Fe}-\mathrm{Cu}) \\
\% \text { weight }\end{array}$ & $\begin{array}{l}\mathrm{N}(\mathrm{Fe}-\mathrm{Cu}) \\
\% \text { weight }\end{array}$ & $\begin{array}{l}\text { AC-phenol } \\
\% \text { weight }\end{array}$ & $\begin{array}{l}\text { CM-phenol } \\
\% \text { weight }\end{array}$ & $\begin{array}{l}\mathrm{CM}(\mathrm{Fe}-\mathrm{Cu}) / \\
\text { Fenton phenol } \\
\% \text { weight }\end{array}$ & $\begin{array}{l}\mathrm{N}(\mathrm{Fe}-\mathrm{Cu}) / \\
\text { Fenton phenol } \\
\% \text { weight }\end{array}$ \\
\hline $\mathrm{C}$ & $82.2 \pm 1.3$ & $59.41 \pm 1.67$ & $62.03 \pm 6.31$ & - & $87.50 \pm 3.89$ & $56.00 \pm 4.02$ & $59.82 \pm 3.29$ & $9.53 \pm 1.71$ \\
$\mathrm{O}$ & $12.3 \pm 1.1$ & $22.75 \pm 1.38$ & $17.54 \pm 3.10$ & $22.41 \pm 7.79$ & $8.53 \pm 3.13$ & $24.11 \pm 3.17$ & $23.55 \pm 3.45$ & $22.54 \pm 6.08$ \\
$\mathrm{Na}$ & $0.6 \pm 0.1$ & $0.37 \pm 0.09$ & $0.42 \pm 0.22$ & - & - & $0.36 \pm 0.09$ & $0.21 \pm 0.05$ & - \\
$\mathrm{Mg}$ & $0.2 \pm 0.0$ & $0.19 \pm 0.14$ & $0.26 \pm 0.04$ & - & $0.35 \pm 0.13$ & $0.21 \pm 0.06$ & $0.32 \pm 0.20$ & - \\
$\mathrm{Al}$ & - & $0.97 \pm 0.12$ & $1.05 \pm 0.42$ & - & - & $1.13 \pm 0.15$ & $1.56 \pm 0.50$ & $0.36 \pm 0.07$ \\
$\mathrm{Si}$ & $0.3 \pm 0.1$ & $11.43 \pm 0.97$ & $11.70 \pm 5.29$ & $0.41 \pm 0.08$ & $0.60 \pm 0.28$ & $12.91 \pm 1.45$ & $8.48 \pm 0.85$ & $0.51 \pm 0.16$ \\
$\mathrm{P}$ & $4.0 \pm 0.3$ & - & $0.28 \pm 0.01$ & - & $2.98 \pm 1.03$ & - & $0.15 \pm 0.02$ & - \\
$\mathrm{S}$ & - & $1.33 \pm 0.35$ & $1.00 \pm 0.09$ & $0.49 \pm 0.23$ & - & $1.25 \pm 0.19$ & $0.75 \pm 0.19$ & - \\
$\mathrm{Cl}$ & - & $0.73 \pm 0.47$ & $0.69 \pm 0.88$ & - & - & $0.58 \pm 0.12$ & $0.39 \pm 0.15$ & $0.14 \pm 0.00$ \\
$\mathrm{~K}$ & - & $0.31 \pm 0.05$ & $0.33 \pm 0.14$ & - & - & $0.28 \pm 0.06$ & $0.34 \pm 0.08$ & - \\
$\mathrm{Ca}$ & - & $1.24 \pm 0.68$ & $2.37 \pm 1.43$ & - & - & $1.81 \pm 0.40$ & $1.82 \pm 0.53$ & - \\
$\mathrm{Fe}$ & $0.4 \pm 0.1$ & $0.94 \pm 0.40$ & $1.87 \pm 0.59$ & $51.62 \pm 14.14$ & $0.31 \pm 09.11$ & $0.94 \pm 0.27$ & $1.83 \pm 0.29$ & $52.49 \pm 6.66$ \\
$\mathrm{Cu}$ & - & - & $0.25 \pm 0.08$ & $25.15 \pm 20.25$ & - & - & $0.50 \pm 0.20$ & $14.52 \pm 2.99$ \\
$\mathrm{Ti}$ & - & $0.45 \pm 0.16$ & $0.43 \pm 0.26$ & - & - & $0.42 \pm 0.07$ & $0.37 \pm 0.07$ & - \\
$\mathrm{Cr}$ & - & - & $0.26 \pm 0.10$ & - & - & - & $0.21 \pm 0.00$ & - \\
\hline
\end{tabular}



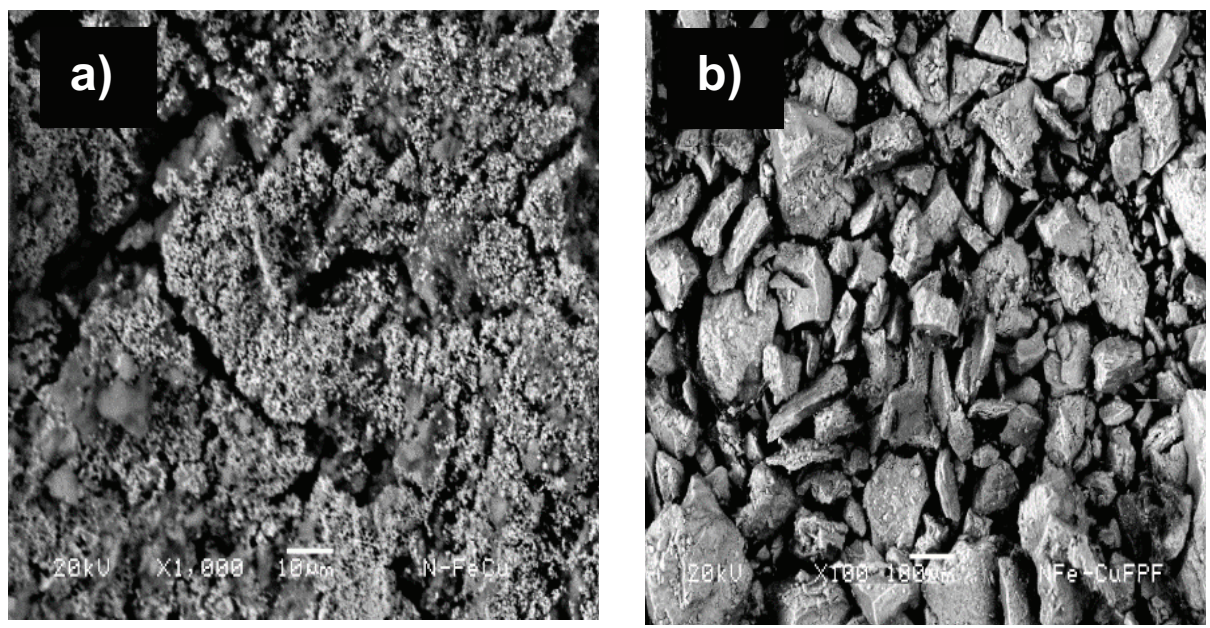

Fig. 3. Scanning-electron micrograph of a) $\mathrm{N}(\mathrm{Fe}-\mathrm{Cu})$ and b) $\mathrm{N}(\mathrm{Fe}-\mathrm{Cu})$ treated with phenol.
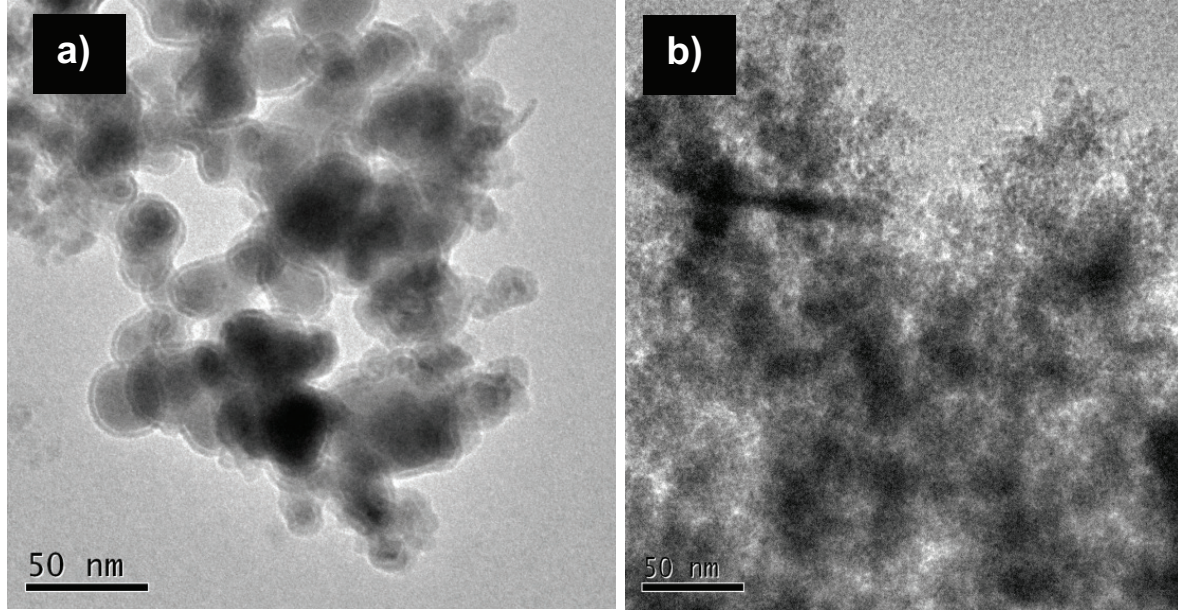

Fig. 4. a) TEM of $\mathrm{N}(\mathrm{Fe}-\mathrm{Cu})$ and b) $\mathrm{N}(\mathrm{Fe}-\mathrm{Cu})$ treated with phenol in presence of hydrogen peroxide.

and $\mathrm{N}(\mathrm{Fe}-\mathrm{Cu})$, respectively. Aluminum, silicon and chlorine were found in trace quantities.

\subsubsection{Transmittance electron microscopy (TEM)}

TEM analysis of raw $\mathrm{N}(\mathrm{Fe}-\mathrm{Cu})$ and the same material after being treated with phenol in the presence of $\mathrm{H}_{2} \mathrm{O}_{2}$ are shown in Fig. $4 a$ and $4 b$, respectively. Their morphologies show mainly laminar particles, iron and copper oxides are observed, and they have a core-shell structure.

\subsubsection{IR spectroscopy}

The IR spectra of CM (Fig. 5a), $\mathrm{CM}(\mathrm{Fe}-\mathrm{Cu})$ (Fig. 5b) and $\mathrm{N}(\mathrm{Fe}-\mathrm{Cu})$ (Fig. 5c) before and after phenol adsorption were similar. The only change observed was a decrease in the intensity of bands. The main adsorption bands observed at $3500 \mathrm{~cm}^{-1}$ correspond to $\mathrm{OH}$ groups. The band from 2850 to $2750 \mathrm{~cm}^{-1}$ corresponds to aromatic and aliphatic groups $\mathrm{CH}_{2}$ and $\mathrm{CH}_{3}$. The band at around $1600 \mathrm{~cm}^{-1}$ corresponds to $\mathrm{C}=\mathrm{C}$ bonds of aromatic groups; bands at 1500 and 1350 $\mathrm{cm}^{-1}$ can be attributed to $\mathrm{CH}_{2}$ and $\mathrm{S}=\mathrm{O}$ groups. Finally, the bands at $1600-1000 \mathrm{~cm}^{-1}$ correspond to $\mathrm{C}-\mathrm{C}$ and $\mathrm{C}-\mathrm{O}$ groups.

\subsubsection{X-ray diffraction}

The diffractograms of the adsorbent materials did not show any significant change after the treatments; only the intensities of some diffraction peaks changed.

Quartz (JCPDS 01086 1629) and albite (JCPDS 01 083 1658) were found in the carbonaceous material, and $\mathrm{CM}(\mathrm{Fe}-\mathrm{Cu})$ showed similar composition. FeO (JCPDS 01 080 2186), $\mathrm{FeOOH}$ (JCPDS 01073 2326) and $\mathrm{Cu}_{2} \mathrm{O}$ (JCPDS 03 0653288 ) were found in $\mathrm{N}(\mathrm{Fe}-\mathrm{Cu})$.

\subsubsection{Specific surface areas}

Table 2 shows the specific surface areas, total pore volumes and mean pore diameters of $\mathrm{AC}, \mathrm{CM}(\mathrm{Fe}-\mathrm{Cu})$ and $\mathrm{N}(\mathrm{Fe}-\mathrm{Cu})$. Activated carbon has the highest specific surface 

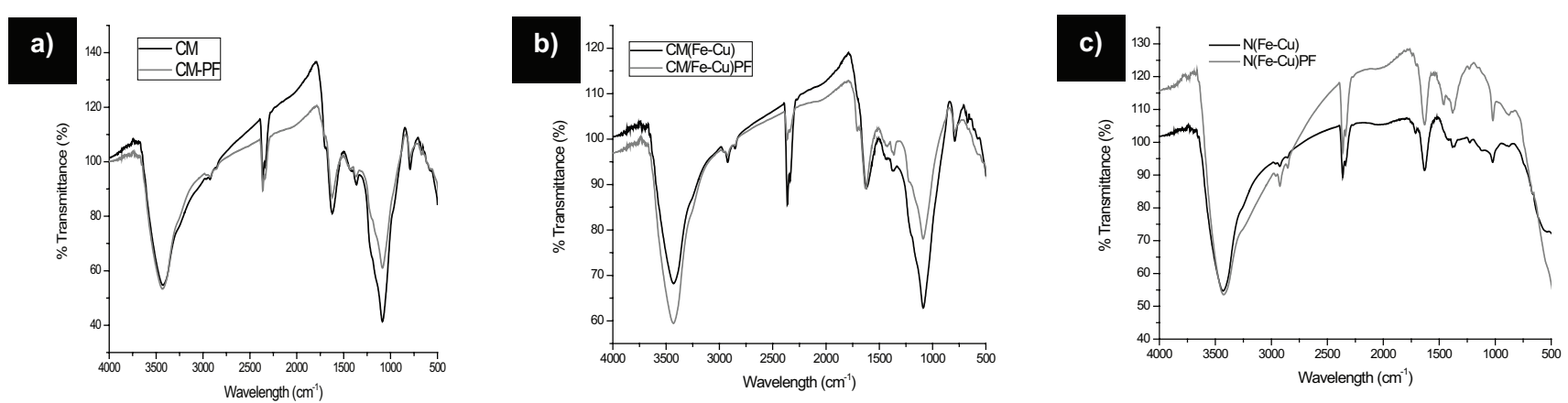

Fig. 5. a) IR spectrum of carbonaceous material and carbonaceous material treated with phenol, b) IR spectrum of composite CM(Fe$\mathrm{Cu})$ and the composite treated with phenol and c) IR spectrum IR of $\mathrm{N}(\mathrm{Fe}-\mathrm{Cu})$ and $\mathrm{N}(\mathrm{Fe}-\mathrm{Cu})$ treated with phenol.

Table 2

Specific surface areas, total pore volumes and mean pore diameters of $\mathrm{AC}, \mathrm{CM}(\mathrm{Fe}-\mathrm{Cu})$ and $\mathrm{N}(\mathrm{Fe}-\mathrm{Cu})$

\begin{tabular}{llll}
\hline Adsorbent & $\begin{array}{l}\text { Specific surface } \\
\text { area }\left(\mathrm{m}^{2} / \mathrm{g}\right)\end{array}$ & $\begin{array}{l}\text { Total pore } \\
\text { volume }\left(\mathrm{m}^{3} / \mathrm{g}\right)\end{array}$ & $\begin{array}{l}\text { Pore diameter } \\
\mathrm{nm}\end{array}$ \\
\hline $\mathrm{AC}$ & 104.29 & 0.1681 & 6.44 \\
$\mathrm{CM}(\mathrm{Fe}-\mathrm{Cu})$ & 75.16 & 0.1745 & 9.28 \\
$\mathrm{~N}(\mathrm{Fe}-\mathrm{Cu})$ & 62.76 & 0.3625 & 23.101 \\
\hline
\end{tabular}

area and $\mathrm{N}(\mathrm{Fe}-\mathrm{CU})$ has the highest total pore volume and pore diameter.

\subsection{Adsorption kinetics}

Fig. 6 shows the kinetic adsorption behavior of phenol by $\mathrm{CM}, \mathrm{AC}, \mathrm{CM}(\mathrm{Fe}-\mathrm{Cu}), \mathrm{N}(\mathrm{Fe}-\mathrm{Cu})$, and in the presence of $\mathrm{H}_{2} \mathrm{O}_{2}$ by $\mathrm{CM}(\mathrm{Fe}-\mathrm{Cu})$ and $\mathrm{N}(\mathrm{Fe}-\mathrm{Cu})$. The equilibrium time was reached in $24 \mathrm{~h}$, the adsorption capacities of phenol at equilibrium were $0.54 \pm 0.05,0.58 \pm 0.12,0.37 \pm 0.02,0.20 \pm 0.24$, $1.85 \pm 0.64$ and $4.44 \pm 0.05 \mathrm{mg} / \mathrm{g}$ for $\mathrm{AC}, \mathrm{CM}, \mathrm{CM}(\mathrm{Fe}-\mathrm{Cu})$, $\mathrm{N}(\mathrm{Fe}-\mathrm{Cu})$ and in the presence of $\mathrm{H}_{2} \mathrm{O}_{2}, \mathrm{CM}(\mathrm{Fe}-\mathrm{Cu})$ and $\mathrm{N}(\mathrm{Fe}-\mathrm{Cu})$ respectively.

The adsorption capacities for phenol are similar for the activated carbon, carbonaceous material and composite $\mathrm{CM}(\mathrm{Fe}-\mathrm{Cu})$, with the latter in the presence and absence of hydrogen peroxide.

The adsorption rate was the highest at the beginning of the process and then diminished up until equilibrium was reached. $\mathrm{N}(\mathrm{Fe}-\mathrm{Cu})$ in the presence and absence of hydrogen peroxide showed the highest adsorption capacities. It is most likely that the oxidation of phenol took place when hydrogen peroxide was present because the removal of phenol increased.

The experimental data were fitted to the kinetic models of Lagergren, Elovich and Ho. The kinetic parameters were determined by fitting the experimental data to these models with the help of Origin ${ }^{\circledR}$ version 8.

\subsubsection{Pseudo-first order model (Lagergren)}

In this model, the sorption rate is proportional to the solute concentration, and it is commonly used for homogeneous sorbents and physical sorption. If the sorption behav-

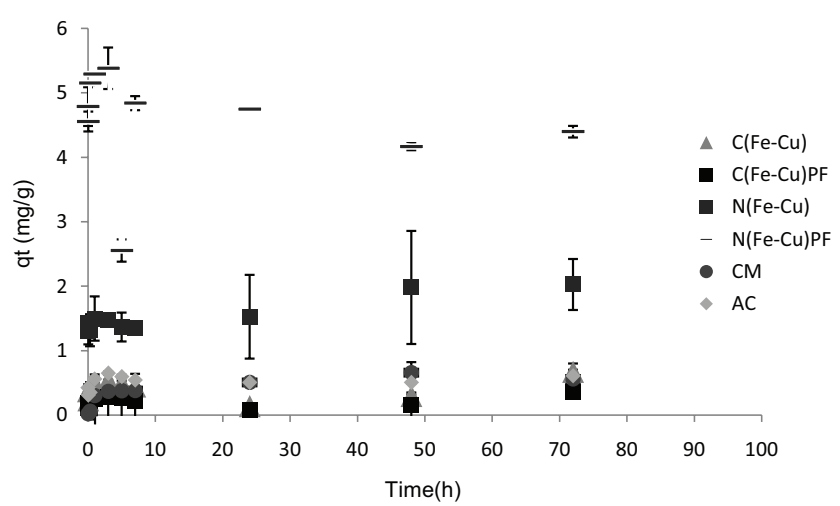

Fig. 6. Kinetic adsorption behavior of phenol by $\mathrm{CM}, \mathrm{AC}, \mathrm{CM}(\mathrm{Fe}-$ $\mathrm{Cu}), \mathrm{N}(\mathrm{Fe}-\mathrm{Cu})$, and in the presence of hydrogen peroxide for the last two materials.

ior is of the first order then the experimental results could be adjusted to the following equation:

$q_{t}=q_{e}\left(1-\mathrm{e}^{K_{L} t}\right)$

where $q_{t}$ and $q_{e}$ are the adsorbed amounts of phenol (mg/g) at time $t(\mathrm{~h})$ and at equilibrium, respectively, and $K_{L}\left(\mathrm{~h}^{-1}\right)$ is the sorption constant of Lagergren [31].

\subsubsection{Second order model (Elovich)}

This model has been used in chemisorptions on highly heterogeneous materials [28], and it is represented by the following equation:

$q_{t}=b \operatorname{In}(a b)+b \operatorname{In}(t)$

where $q_{t}$ is the amount of adsorbed phenol at time $t, a$ is the sorption constant of phenol $(\mathrm{mg} / \mathrm{g})$ and $b$ is the desorption constant $(\mathrm{mg} / \mathrm{g})[32]$.

\subsubsection{Pseudo-second order model}

The pseudo-second order model [31] is based on the assumption that the rate limiting step may be chemisorption involving valence forces through sharing or exchange 
of electrons between adsorbent and adsorbate. This model can be represented in the following form:

$$
q_{t}=\frac{q_{e}^{2} k t}{1+q_{e} k t}
$$

where $q_{t}$ and $q_{e}$ are the amounts of adsorbed phenol at time $t$ and at equilibrium $(\mathrm{mg} / \mathrm{g})$, respectively; $k$ is the pseudo-second order rate constant for the sorption process $(\mathrm{g} /$ $\mathrm{mgh}$ ).

The experimental kinetic data were adjusted to these kinetic models, but only the data of AC and CM could be adjusted to these models, and the kinetic parameters obtained are shown in Table 3. Fig. 7 shows the kinetic adsorption behavior of phenol by carbonaceous material and activated carbon fitted to the models. The results show that the experimental data of both materials were best adjusted to second order model, indicating that the adsorption mechanism is chemisorption [31]. The adsorption of phenol is stronger than the desorption process in the case of the activated carbon, and an opposite behavior was observed for the carbonaceous material.

\subsection{Adsorption isotherms}

Fig. 8 shows the adsorption isotherms of phenol by the materials at $30^{\circ} \mathrm{C}$, all isotherms are linear and this behav- ior is characteristic of the partition mechanism $[33,34]$. The mechanism considers that phenol is retained on the external surface of the adsorbents. The distribution coefficient $\left(K_{d}\right)$ is the slope of the obtained isotherm. The distribution and the determination $\left(R^{2}\right)$ coefficients for each material are shown in Table 4. A similar behavior was reported by Cortés-Martínez et al. (2007) [33] for the adsorption of 4-chloride phenol by a surfactant modified zeolitic tuff. Linear isotherms indicate that adsorption capacities increase proportionally as the quantities of solutes increase in the adsorption systems.

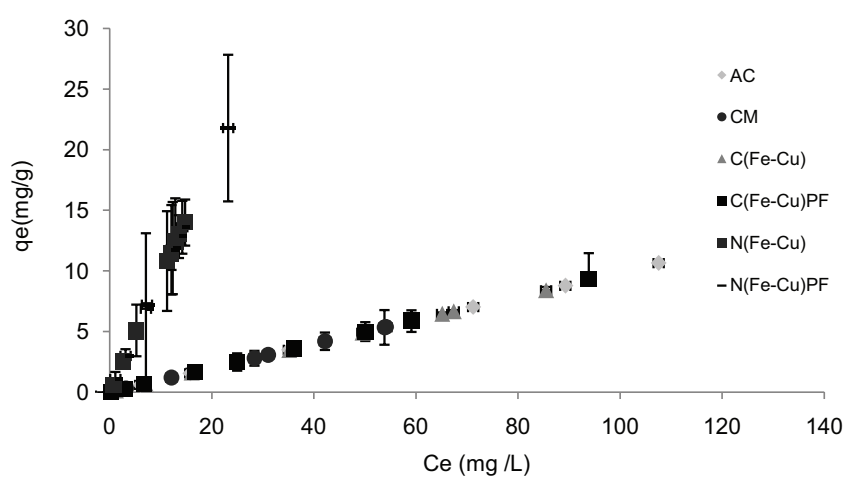

Fig. 8. Adsorption isotherms of phenol at $30^{\circ} \mathrm{C}$.

Table 3

Kinetic parameters calculated by fitting the experimental data to models

\begin{tabular}{|c|c|c|c|c|c|c|c|c|c|}
\hline \multirow[t]{3}{*}{ Material } & \multicolumn{9}{|c|}{ Kinetic models } \\
\hline & \multicolumn{3}{|c|}{ Pseudo-first order } & \multicolumn{3}{|c|}{ Second order } & \multicolumn{3}{|c|}{ Pseudo-second order } \\
\hline & $\begin{array}{l}q_{e} \\
(\mathrm{mg} / \mathrm{g})\end{array}$ & $\begin{array}{l}K_{L} \\
\left(h^{-1}\right) \\
\end{array}$ & $R^{2}$ & $\begin{array}{l}a \\
(\mathrm{mg} / \mathrm{g})\end{array}$ & $\begin{array}{l}b \\
(\mathrm{mg} / \mathrm{g})\end{array}$ & $R^{2}$ & $\begin{array}{l}q_{e} \\
(\mathrm{mg} / \mathrm{g})\end{array}$ & $\begin{array}{l}\text { K } \\
\text { (g/mgh) }\end{array}$ & $R^{2}$ \\
\hline $\mathrm{AC}$ & 0.47 & 140.46 & 0.6875 & 183118.31 & 37.01 & 0.9050 & 0.50 & 293.26 & 0.7435 \\
\hline $\mathrm{CM}$ & 0.54 & 0.33 & 0.8950 & 0.99 & 10.54 & 0.9530 & 0.58 & 0.95 & 0.9418 \\
\hline
\end{tabular}
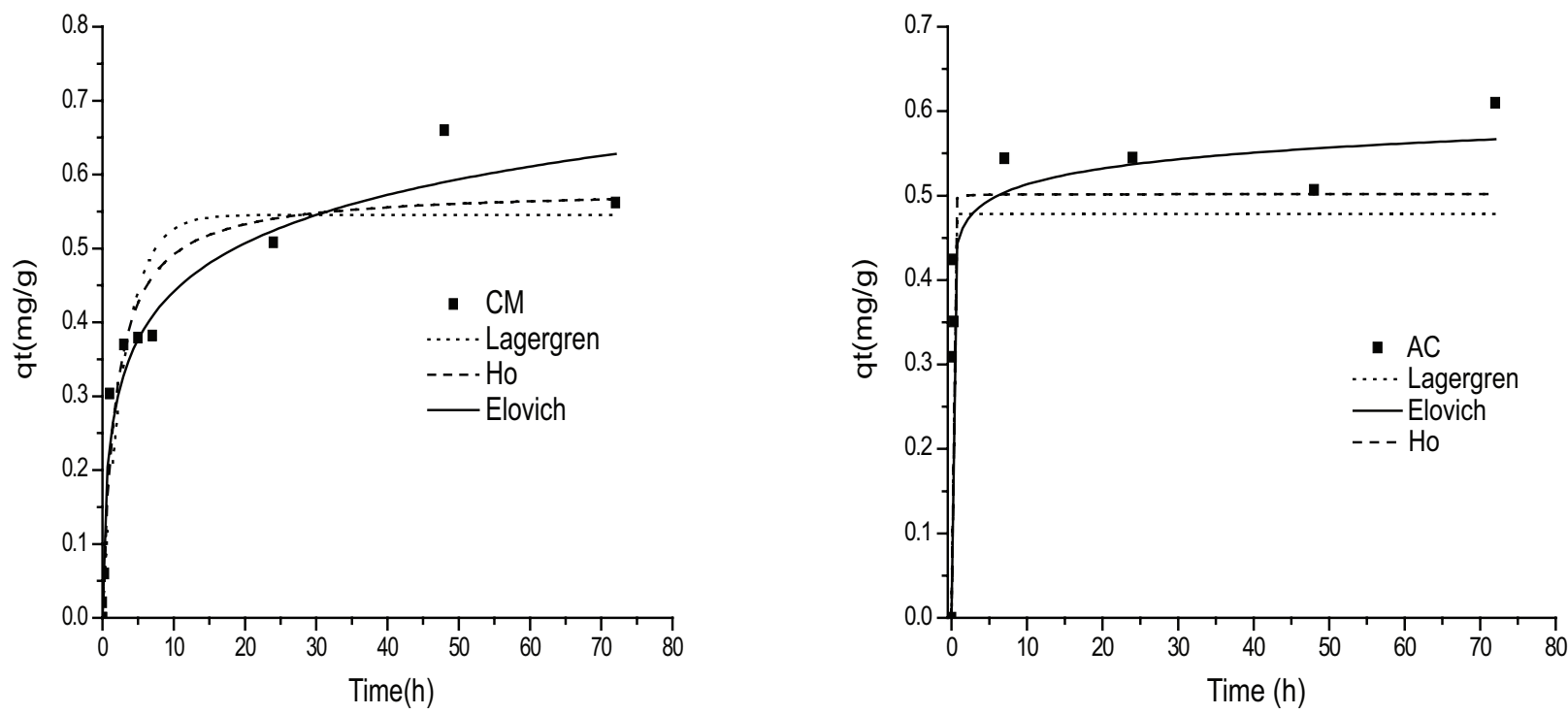

Fig. 7. Kinetic models applied to phenol sorption from aqueous solution by carbonaceous material (a) and activated carbon (b). 
Table 4

Parameters of the lineal adsorption isotherms

\begin{tabular}{lll}
\hline Material & $K_{d}$ & $R^{2}$ \\
\hline $\mathrm{AC}$ & 0.0957 & 0.9998 \\
$\mathrm{CM}$ & 0.0982 & 0.9998 \\
$\mathrm{CM}(\mathrm{Fe}-\mathrm{Cu})$ & 0.0987 & 0.9987 \\
$\mathrm{CM}(\mathrm{Fe}-\mathrm{Cu}) \mathrm{PF}$ & 0.0973 & 0.9999 \\
$\mathrm{~N}(\mathrm{Fe}-\mathrm{Cu})$ & 0.9755 & 0.9994 \\
$\mathrm{~N}(\mathrm{Fe}-\mathrm{Cu}) \mathrm{PF}$ & 0.9616 & 0.9988 \\
\hline
\end{tabular}

Phenol showed a higher affinity for $\mathrm{N}(\mathrm{Fe}-\mathrm{Cu})$ in the absence and presence of $\mathrm{H}_{2} \mathrm{O}_{2}$ than the other materials. The values of $K_{d}$ for $\mathrm{N}(\mathrm{Fe}-\mathrm{Cu})$ in the absence and presence of $\mathrm{H}_{2} \mathrm{O}_{2}$ were ten times higher than the values found for AC, $\mathrm{CM}$ and $\mathrm{CM}(\mathrm{Fe}-\mathrm{Cu})$.

\subsection{Effect of $p H$}

$\mathrm{pH}$ is an important parameter in sorption due to potential ionization of the contaminants, functional groups of adsorbent surface and composition of solutions. Fig. 9 shows the phenol sorption capacities at various $\mathrm{pH}$ values for $\mathrm{CM}$, $\mathrm{AC}, \mathrm{CM}(\mathrm{Fe}-\mathrm{Cu})$ and $\mathrm{N}(\mathrm{Fe}-\mathrm{Cu})$ in the presence of $\mathrm{H}_{2} \mathrm{O}_{2}$.

The adsorption capacity of $\mathrm{CM}(\mathrm{Fe}-\mathrm{Cu})$ for phenol was not affected by the $\mathrm{pH}$. This behavior indicates that neither the chemical species in solution nor the effects of $\mathrm{pH}$ on the material are important parameters in the sorption process of phenol. The adsorption capacities for $\mathrm{CM}$ and $\mathrm{AC}$ decreased as the $\mathrm{pH}$ increased which could suggest that the neutral species of phenol are retained by these materials, and this behavior could indicate a partition mechanism. Cortes et al. [33] found that the adsorption of 4 chloro phenol by a surfactant modified zeolitic material was similar in the $\mathrm{pH}$ range between 5 and 9.5 .

The adsorption capacity of $\mathrm{N}(\mathrm{Fe}-\mathrm{Cu})$ was similar in the $\mathrm{pH}$ range from 4 to 10 . ElShafei et al. [20] reported that the degradation of nitro-benzene by oxides of $\mathrm{Fe}$ and $\mathrm{Cu}$ was best accomplished at $\mathrm{pH}$ of 7 . Babuponnusami and Muthukumar [9] reported the removal of phenol by electro photo Fenton using nanoparticles of iron, and they found that the $\mathrm{pH}$ is a very important parameter in the process. It has been found that oxidation is better accomplished at $\mathrm{pH}$ of 3 . Shimizu et al. [12] found that the best $\mathrm{pH}$ for the removal of phenol is 3 , using iron in the presence of dissolved oxygen.

\subsection{Effect of the adsorbent dosage}

Fig. 10 shows the adsorption capacities of AC, MC, $\mathrm{CM}(\mathrm{Fe}-\mathrm{Cu}), \mathrm{N}(\mathrm{Fe}-\mathrm{Cu}), \mathrm{CM}(\mathrm{Fe}-\mathrm{Cu}) \mathrm{PF}$ and $\mathrm{N}(\mathrm{Fe}-\mathrm{Cu}) \mathrm{PF}$ vs. adsorbent dosage. The sorption capacities for phenol decreased with an increase in the adsorbent dosage from 1 to $20 \mathrm{mg}$ of adsorbent; this behavior could be attributed to the adsorption sites remaining unsaturated during the adsorption reaction [3]. Similar results were reported by Dehghani et al. [15] for the adsorption of 2,4-dichlorophenolyxacetic acid $(2,4-\mathrm{D})$ herbicide by granular activated carbon. A degradation mechanism of phenol using ferric ions and $\mathrm{Fe} / \mathrm{Cu}$ bimetallic catalysis has been proposed elsewhere $[8,35]$.

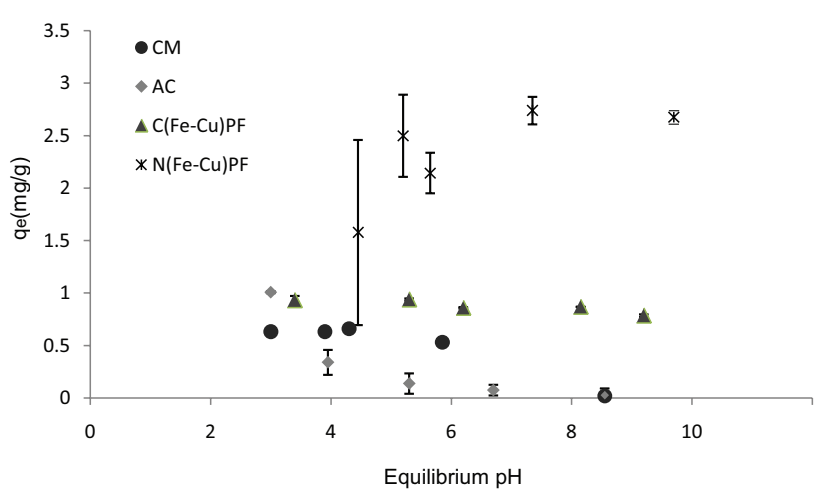

Fig. 9. Equilibrium $\mathrm{pH}$ values vs. adsorption capacities of phenol.

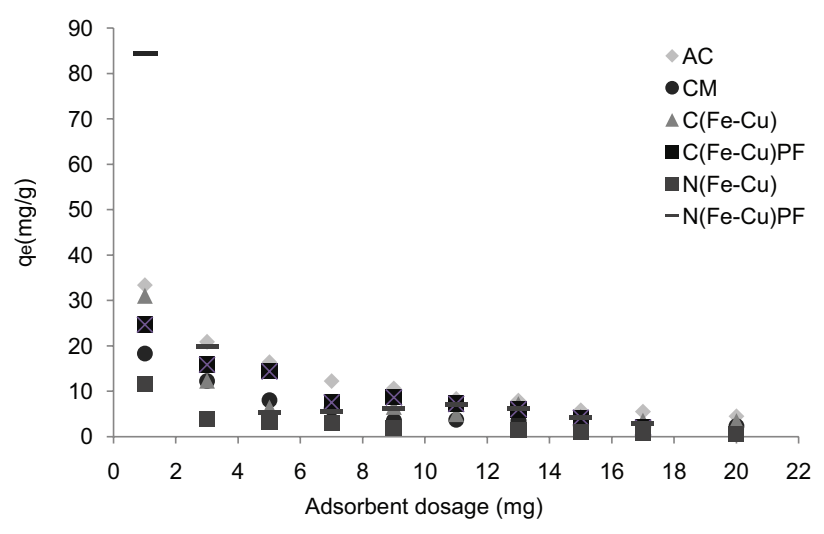

Fig. 10. Adsorbent dosages vs. adsorption capacities of phenol.

\subsection{Effect of temperature}

The effect of temperature on the adsorption of phenol was determined at 30 (Fig. 8), 40 and $50^{\circ} \mathrm{C}$ for $\mathrm{CM}, \mathrm{AC}$, $\mathrm{CM}(\mathrm{Fe}-\mathrm{Cu})$ and $\mathrm{N}(\mathrm{Fe}-\mathrm{Cu})$, the last two in both the absence and presence of $\mathrm{H}_{2} \mathrm{O}_{2}$. In general, the adsorption capacities for all materials were similar at the different temperatures. Fig. 11 shows the adsorption isotherms of phenol by the materials at $50^{\circ} \mathrm{C}$; only $\mathrm{CM}(\mathrm{Fe}-\mathrm{Cu})$ in the absence and presence of $\mathrm{H}_{2} \mathrm{O}_{2}$ showed that the adsorption increased with the temperature increase from 40 to $50^{\circ} \mathrm{C}$. This behavior may indicate that at $50^{\circ} \mathrm{C}$, the oxidation of phenol may take place or that the adsorption process is endothermic. The thermodynamic parameters of these processes could not be calculated because the adsorption systems showed similar behaviors in this temperature range. Wang et al. [10] reported the catalytic degradation of phenol by the Fenton process, and they found that the degradation increased as the temperature increased from $40^{\circ} \mathrm{C}$ to $50^{\circ} \mathrm{C}$.

The results show that carbonaceous material obtained from the pyrolysis of sewage sludge $(\mathrm{CM})$, composite $\mathrm{CM}(\mathrm{Fe}-\mathrm{Cu})$ and nanoparticles $\mathrm{N}(\mathrm{Fe}-\mathrm{Cu})$ may be alternative adsorbents for the removal of phenol. These new adsorbents have economic advantages because of their low cost, and adsorption properties. It would be interesting to investigate their adsorption properties in larger scale (technical and economic aspects). 


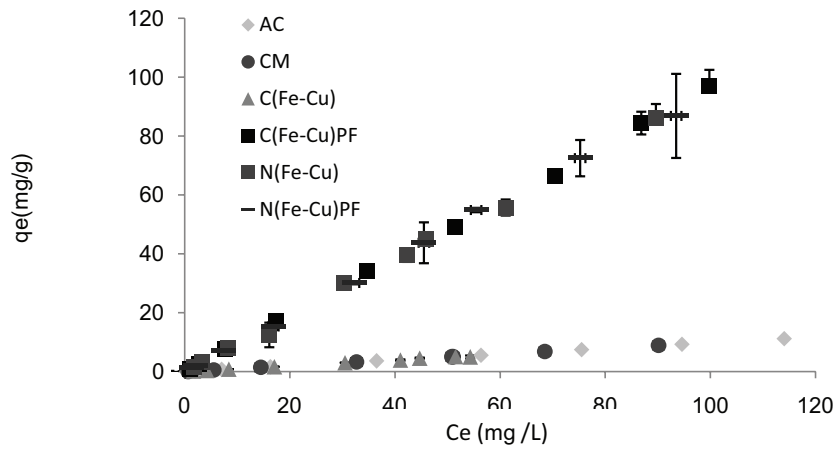

Fig. 11. Adsorption isotherms of phenol at $50^{\circ} \mathrm{C}$.

\section{Conclusions}

Different carbonaceous materials and $\mathrm{Fe}-\mathrm{Cu}$ nanoparticles were characterized by BET, infrared spectroscopy, X-ray diffraction and SEM-EDS; the presence of $\mathrm{Fe}-\mathrm{Cu}$ nanoparticles was confirmed by the TEM technique. The experimental kinetic data of the activated carbon and the carbonaceous material were treated with Lagergren, Elovich and Ho models. The results show that both materials are best fit to the second order model indicating a chemisorption mechanism. The adsorption equilibrium of phenol by the different adsorption materials was observed in $24 \mathrm{~h}$. The adsorption capacity of $\mathrm{CM}(\mathrm{Fe}-\mathrm{Cu})$ for phenol was not affected by the $\mathrm{pH}$, and the adsorption capacities for $\mathrm{CM}$ and $\mathrm{AC}$ decreased as the $\mathrm{pH}$ increased. The presence of hydrogen peroxide in the composite was important for the removal of phenol from the aqueous solutions. The composite (carbonaceous material $\mathrm{Fe}-\mathrm{Cu}$ ) showed higher efficiency for the removal of phenol than the carbonaceous material; therefore, the first one could be used as an alternative material for treating residual industrial water. The highest adsorption capacities were for $\mathrm{N}(\mathrm{Fe}-\mathrm{Cu})$ in the presence and absence of hydrogen peroxide. The adsorption capacities decreased as the doses increased and the adsorption capacities of the materials were not affected by the temperature when it was between 30 and $50^{\circ} \mathrm{C}$.

\section{Acknowledgements}

The authors would like to acknowledge the financial support from UAEM, proyect 3688/2014/CIB and CONACYT, project 131174Q and scholarship No. 290817 for YSPH.

\section{References}

[1] H. Dhaouadi, F. M'Henni, Textile mill effluent decolorization using crude dehydrated sewage sludge, Chem. Eng. J., 138 (2008) 111-119.

[2] Q.-Y. Cai, C.-H. Mo, Q.-T. Wu, Q.-Y. Zeng, A. Katsoyiannis, Occurrence of organic contaminants in sewage sludges from eleven wastewater treatment plants, China, Chemosphere, 68 (2017) 1751-1762.

[3] E. Gutiérrez-Segura, M. Solache-Ríos, A. Colín-Cruz, C. Fall, Adsorption of cadmium by Na and Fe modified zeolitic tuffs and carbonaceous material from pyrolyzed sewage sludge, J. Environ. Manage., 97 (2012) 6-13.

[4] B. Ayodele, K. Lim, H. Hameed, Degradation of phenol in photo-Fenton process by phosphoric acid modified kaolin supported ferric-oxalate catalyst: Optimization and kinetic modeling, Chem. Eng. J., 197 (2012) 181-192.
[5] NOM-127-SSA1-1994, Salud ambiental, agua para uso y consumo humano-límites permisibles de calidad y tratamientos a que debe someterse el agua para su potabilización. Diario Oficial de la Federación 20 de octubre de 2000

[6] H. Kušić, N. Koprivanac, AL. Bŏzić, I. Selanec, Photo-assisted Fenton type processes for the degradation of phenol: A kinetic study, J. Hazard. Mater., 136 B (2006) 632-644.

[7] P. Girods, A. Dufour, V. Fierro, Y. Rogaume, C. Rogaume, A. Zoulalian, A. Celzard, Activated carbons prepared from wood particleboard wastes: and phenol adsorption capacities, J. Hazard. Mater., 166 (2009) 491-501.

[8] Y.H. Huang, Y.J. Huang, H.C. Tsai, H.T. Chen, Degradation of phenol using low concentration of ferric ions by the photo-Fenton process, J. Taiwan Inst. Chem. Eng., 41 (2010) 699-704.

[9] A. Babuponnusami, K. Muthukumar, Removal of phenol by heterogenous photo electro Fenton-like process using nanozero valent iron, Sep. Purif. Technol., 98 (2012)130-135.

[10] W. Wang, Y. Liu, T. Li, M. Zhou, Heterogeneous Fenton catalytic degradation of phenol based on controlled release of magnetic nanoparticles, Chem. Eng. J., 242 (2014) 1-9.

[11] G. Zelmanov, R. Semiat, Phenol oxidation kinetics in water solution using iron(3)-oxide-based nano-catalysts, Water Res., 42 (2008) 3848-3856.

[12] A. Shimizu, M. Tokumura, K. Nakajima, Y. Kawase, Phenol removal using zero-valent iron powder in the presence of dissolved oxygen: Roles of decomposition by the Fenton reaction and adsorption/precipitation, J. Hazard. Mater., 201-202 (2012) 60-67.

[13] C. Fan, C.Y. Horng, S.J. Li, Structural characterization of natural organic matter and its impact on methomyl removal efficiency in Fenton process, Chemosphere, 93 (2013) 78-83.

[14] S. Wang, Y. Boyjoo, A. Choueib, Z.H. Zhu, Removal of dyes from aqueous solution using fly ash and red mud, Water Res., 39 (2005) 129-138.

[15] M. Dehghani, S. Nasseri, M. Karamimanesh, Removal of 2,4-dichlorophenolyxacetic acid(2,4-D) herbicide in the aqueous phase using modified granular activated carbon, J. Environ. Health Sci. Eng. 12 (2014) 1-28.

[16] V.K. Gupta, Suhas, Application of low-cost adsorbents for dye removal-A review, J. Environ. Manage., 90 (2009) 2313-2342.

[17] A.S. Kilinc, Ö. Özbayrak,S. Alpat, The adsorption kinetics and removal of cationic dye, Toluidine Blue $\mathrm{O}$, from aqueous solution with Turkish zeolite, J. Hazard. Mater., 151 (2008) 213-220.

[18] E.G. Garrido, B.K.G. Theng, M.L. Mora, Clays and oxide minerals as catalysts and nanocatalysts in Fenton-like reactions-A review, Appl. Clay Sci., 47 (2010) 182-192.

[19] K. Rusevova, F. Kopinke, A. Georgi, Nano-sized magnetic iron oxides as catalysts for heterogeneous Fenton-like reactionsInfluence of $\mathrm{Fe}(\mathrm{II}) / \mathrm{Fe}$ (III) ratio on catalytic performance, J. Hazard. Mater., 241-242 (2012) 433-440.

[20] G.M.S. ElShafei, F.Z. Yehia, O.I.H. Dimitry, A.M. Badawi, Gh. Eshaq, Ultrasonic assisted-Fenton-like degradation of nitrobenzene at neutral $\mathrm{pH}$ using nanosized oxides of $\mathrm{Fe}$ and $\mathrm{Cu}$, Ultrason. Sonochem., 21 (2014) 1358-1365.

[21] B. Iurascu, I. Siminiceanu, D. Vione, M.A. Vicente, A. Gil, Phenol degradation in water through a heterogeneous photo-Fenton process catalyzed by Fe-treated laponite, Water Res., 43 (2009) 1313-1322.

[22] J. Camilo-García, M. Castellanos, A. Uscátegui, J. Fernández, A.M. Pedroza, C.E. Daza, Remoción de colorantes sintéticos mediante el proceso Fenton heterogéneo usando $\mathrm{Fe}_{2} \mathrm{O}_{3}$ soportado en carbón activado obtenido a partir de residuos de rosas, Univ. Sci., 17 (2012) 303-314.

[23] P.V. Nidheesh, R. Gandhimathi, Trends in electro-Fenton process for water and wastewater treatment: An overview, Desalination, 299 (2012) 1-15.

[24] S.P. Sun, A.T. Lemley, p-Nitrophenol degradation by a heterogeneous Fenton-like reaction on nano-magnetite: Process optimization, kinetics, and degradation pathways, J. Mol. Catal. A: Chem., 349 (2011) 71-79.

[25] W. Wang, M. Zhou, Q. Mao, J. Yue, X. Wang, Novel NaY zeolite-supported nanoscale zero-valent iron as an efficient heterogeneous Fenton catalyst, Catal. Commun., 11 (2010) 937-941. 
[26] K. Choi, W. Lee, Enhanced degradation of trichloroethylene in nano-scale zero-valent iron Fenton system with $\mathrm{Cu}(\mathrm{II}), \mathrm{J}$. Hazard. Mater., 211- 212 (2012) 146- 153.

[27] J. Trujillo-Reyes, M. Solache-Ríos, A. Vilchis, V. Sánchez-Mendieta, A. Colín-Cruz, Removal of remazol yellow from aqueous solution using $\mathrm{Fe}-\mathrm{Cu}$ and $\mathrm{Fe}-\mathrm{Ni}$ nanoscale oxides and their carbonaceous composites, Environ. Technol., 33 (2012) 545-554.

[28] R. Cortés-Martínez, V. Martínez, M. Solache-Ríos, Evaluation of natural and surfactant modified zeolites in the removal of cadmium from aqueous solutions, Sep. Sci. Technol., 39 (2004) 2711-2730.

[29] M. Vinita, R. Dorathi, K. Palanivelu, Degradation of 2,4,6-trichlorophenol by photo Fenton's like method using nano heterogeneous catalytic ferric ion, Sol. Energy., 84 (2010) 1613-1618.

[30] E. Gutierrez-Segura, M. Solache-Rios, A. Colin-Cruz, Sorption of indigo carmine by a Fe-zeolitic tuff and carbonaceous material from pyrolyzed sewage sludge, J. Hazard. Mater., 170 (2009) 1227-1235.
[31] Y.S. Ho, Review of second-order models for adsorption systems, J. Hazard. Mater., 136 B (2006) 681-689.

[32] Y.S. Ho, G. McKay, Application of kinetic models to the sorption of copper (II) on to peat, Adsorpt. Sci. Technol., 20 (2002) 183-191.

[33] R. Cortés-Martínez, V. Martínez-Miranda, M. Solache-Ríos, R.Cuevas, Sorption behavior of 4-chlorophenol from aqueous solutions by a surfactant-modified mexican zeolitic rock in batch and fixed bed systems, Water Air Soil Pollut., 183 (2007) 85-94.

[34] C. Díaz Nava, M.T. Olguín, M. Solache-Ríos, T. Alarcon Herrera, A. Aguilar, Phenol sorption on surfactant-modified Mexican zeolitic-rich tuff in batch and continuous systems, J. Hazard. Mater., 167 (2009) 1063-1069.

[35] L. Sun, H. Song, Q. Li, A. Li, Fe/Cu bimetallic catalysis for reductive degradation of nitrobenzene under oxic conditions, Chem. Eng. J., 283 (2016) 366-374. 